\title{
Analisis Pengembangan Produk Turunan Kelapa Di Provinsi Gorontalo
}

\author{
Sri Indriyani S. Dai ${ }^{1}$ \\ Universitas Negeri Gorontalo \\ e-mail: Indriyanidaiseme24@ gmail.com \\ Melan A. Asnawi ${ }^{2}$ \\ Universitas Negeri Gorontalo \\ ABSTRAK
}

Tujuan penelitian ini adalah untuk menganalisis pengembangan produk turunan kelapa di Provinsi Gorontalo. Target spesifik yang ingin dicapai dalam penelitian ini adalah menghasilkan daftar produk turunan kelapa potensial yang akan dikembangkan di Provinsi Gorontalo. Lokasi penelitian ini di semua kabupaten / kota di Provinsi Gorontalo khususnya di sentra produksi kelapa. Metode penelitian yang digunakan berupa metode penelitian eksploratori yang diawali dengan pencarian potensi produk turunan kelapa. Analisis yang akan digunakan untuk penelitian ini adalah analisis AHP (Analytical Hierarchy Process) dan analisis ECM (Exponential Comparison Matrix). Hasil analisis Dari beberapa alternatif produk turunan kelapa yang telah dikembangkan di masyarakat, produk minyak goreng merupakan produk turunan kelapa yang paling potensial untuk dikembangkan lebih lanjut. Produk minyak goreng memiliki keuntungan dalam hal permintaan pasar yang sangat tinggi, proses produksi yang kurang kompleks dan teknologi produksi yang cukup sederhana. Selain itu, produk minyak goreng juga telah banyak dikembangkan oleh masyarakat secara tradisional.

Kata kunci: Proses Hirarki Analitik, Matriks Perbandingan Eksponensial, Produk Berasal dari Kelapa.

ABSTRACT

The purpose of this study is to analyze the development of coconut derived products in the province of Gorontalo. The specific target to be achieved in this research is to produce a list of potential coconut derived products to be developed in Gorontalo Province. The location of this research in all regencies / cities in Gorontalo Province especially in coconut producing centers. The research method used in the form of exploratory research method that begins with the searching of potential coconut derived products. The analysis to be used for this research is AHP (Analytical Hierarchy Process) analysis and ECM analysis (Exponential Comparison Matrix). The results of the analysis From several alternative coconut derived products that have been developed in the community, cooking oil products are the most potential derived coconut products to be developed further. Cooking oil products have an advantage in terms of very high market demand, less complex production processes and fairly simple production technology. In addition, cooking oil products have also been widely developed by the community traditionally.

Keywords: Analytical Hierarchy Process, Exponential Comparison Matrix, Coconut Derived Product

Jurnal Frontiers Volume 1 Nomor 1, April 201817

P-ISSN: 2621-0991 E-ISSN: 2621-1009 


\section{PENDAHULUAN}

Provinsi Gorontalo merupakan salah satu provinsi memiliki potensi areal perkebunan kelapa yang besar, tersebar diberbagai Kabupaten. Berdasarkan data yang ada, terdapat 11 jenis tanaman perkebunan yang dibudidayakan oleh Rakyat. Areal perkebunan yang paling dominan adalah tanaman kelapa (dengan luasan mencapai 44.420,44 ha) diikuti oleh kemiri, kakao, cengkeh, aren dan kopi (Miftahorrahman, 2008). Kendala utama dalam pengembangan agribisnis kelapa di Gorontalo, sebagaimana di provinsi lainnya, adalah rendahnya produktivitas tanaman (Tenda 2009), yakni rata-rata hanya 1 ton kopra/ha/tahun. Sehingga dibutuhkan program yang ditujukan untuk meningkatkan produktivitasnya.

Berdasarkan data produksi kelapa yang diperoleh dari Dinas Pertanian, menunjukkan bahwa dari 6 daerah tingkat dua yang ada di wilayah Provinsi Gorontalo, 4 kabupaten yang memiliki kultivar kelapa lokal yang mempunyai potensi produktivitas dan kualitas yang tinggi, yakni Kabupaten Bone Bolango, Kabupaten Gorontalo, Kabupaten Boalemo dan Kabupaten Pohuwato.

Agribisnis kelapa di Provinsi Gorontalo perlu terus ditingkatkan karena potensi pengembangannya cukup besar. Hal ini dapat dilihat dari ketersediaan lahan yang luas. Pengembangan produk turunan kelapa diharapkan akan memberi manfaat pada kehidupan petani yang lebih layak, petani menjadi pelaku agribisnis kelapa, tumbuhnya semangat petani untuk melakukan usaha tani secara efisien. Selain Itu bahan baku kontinu untuk pengolahan tingkat kelompok tani/gabungan kelompok tani (Gapoktan) dan industri pengolahan dapat terpenuhi, serta kelembagaan petani dalam bentuk kelompok tani/gapoktan untuk memudahkan transfer teknologi dalam pengembangan usaha tani dan produk turunan kelapa dapat tumbuh dan berkembang

Berdasarkan latar belakang permasalahan di atas, masalah yang ingin diteliti dalam penelitian ini adalah: "Bagaimana perkembangan produk turunan kelapa di Provinsi Gorontalo".

Dalam melakukan penelitian ini teori yang dijadikan dasar analisis diuraikana sebagai berikut:

\section{1) Buah Kelapa}

Kelapa adalah salah satu jenis tanaman palem yang tersebar di hampir semua negara tropis, terutama di daerah dekat pantai. Hal ini merupakan petunjuk bahwa tanaman kelapa berasal dari daerah tropis, walaupun sulit menentukan negara mana tepatnya. Kelapa dikenal sebagai tanaman serba guna karena seluruh bagian tanaman ini bermanfaat bagi kehidupan manusia (Palungkun, 1998).

Palungkun (1998) menyatakan bahwa pada mulanya hanya ada dua varietas kelapa yang dikenal, yaitu varietas dalam (tall variety) dan varietas genjah (dwarf variety). Setiap tipe kelapa baik kelapa dalam maupun kelapa genjah terdiri atas beberapa kultivar. Kelapa dalam Mapanget, kelapa dalam Tenga, kelapa dalam Palu dan kelapa dalam Bali adalah kultivar-kultivar kelapa dalam unggul (Pusat Penelitian dan Pengembangan Perkebunan, 2005).

Kelapa varietas dalam terdapat di berbagai negara produsen kelapa. Varietas ini berbatang tinggi dan besar, tingginya mencapai tiga puluh meter atau lebih. Umurnya dapat mencapai lebih dari seratus tahun. Keunggulan varietas ini adalah (Palungkun, 1998) :

1. Produksi kopranya lebih tinggi, yaitu sekitar satu ton kopra/ha/tahun pada umur sepuluh tahun,

2. Daging buah tebal dan keras dengan kadar minyak yang tinggi, dan

3. Lebih tahan terhadap hama penyakit 
Kekurangan dari kelapa varietas dalam adalah :

1. Lambat berbuah (6-7 tahun setelah tanam),

2. Produksi tandan buah sedikit, yaitu sekitar 11 tandan/pohon/tahun,

3. Produktivitas sekitar 90 butir/pohon/tahun, dan

4. Habitus tanaman lebih tinggi, yaitu sekitar 20 meter pada umur 50 tahun.

Tanaman kelapa varietas genjah berbatang ramping, tinggi batang mencapai 5 meter atau lebih, masa berbuah 3-4 tahun setelah tanam, dan dapat mencapai umur 50 tahun. Kelebihan kelapa varietas genjah yaitu lebih cepat berbuah, produksi tandan buah lebih banyak (sekitar 18 tandan/pohon/tahun), habitus tanaman pendek dan produktivitas sekitar 140 butir/pohon/tahun. Kekurangan dari kelapa varietas genjah yaitu produksi kopra rendah (sekitar 0,5 ton/ha/tahun pada umur 10 tahun), daging buah tebal, rapuh dan kandungan minyaknya rendah, serta peka terhadap gangguan hama dan penyakit (Palungkun, 1998).

\section{2) Produk Turunan Kelapa}

Kelapa dijuluki pohon kehidupan, karena setiap bagian tanaman dapat dimanfaatkan. Bunga kelapa menghasilkan nira kelapa yang dapat menghasilkan gula merah (gula kelapa); Daging buah kelapa dapat menghasilkan kopra, minyak kelapa, santan, dan kelapa parut kering (desiccated coconut); Sabut kelapa dapat menghasilkan coir fiber, keset, sapu, matras, dan bahan pembuat spring bed; Tempurung kelapa dapat dimanfaatkan menjadi arang tempurung, karbon aktif, dan kerajinan tangan; Air kelapa dapat dimanfaatkan sebagai bahan cuka, nata de coco, kecap, dan minuman berenergi; Batang kelapa dapat dimanfaatkan untuk bahan bangunan kerangka atau atap; Daun kelapa dapat menghasilkan lidi untuk sapu serta barang anyaman sebagai dekorasi;
Akar kelapa dapat dimanfaatkan sebagai bahan pewarna dan obat-obatan (Jamaran, 2009) Bunga kelapa yang belum mekar dapat disadap untuk menghasilkan nira kelapa. Nira ini digunakan sebagai bahan baku produk gula kelapa, selain itu bunga kelapa juga digunakan untuk kerajinan hiasan dinding dan dekorasi. Pelepah kelapa dapat dibuat sebagai kerajinan, seperti topi dan kipas. Air kelapa, selain dapat diminum langsung dapat diolah menjadi sirup, nata de coco, kecap, minuman isotonik dan lain-lain.

Tempurung kelapa dapat dimanfaatkan berbagai industri seperti arang dan karbon aktif yang berfungsi untuk mengabsorbsi gas selain sebagai barang kerajinan, alat rumah tangga dan barangbarang seni lainnya, seperti ikat pinggang, gelang, sendok, asbak, kancing dan hiasan dinding. Sabut kelapa dapat dijadikan sebagai bahan baku aneka industri, seperti karpet, sikat, bahan pengisi jok mobil, tali dan lain-lain. Sabut gabus kelapa dapat dibuat pot bunga. Sabut berkaret bisa dibuat batako dan kasur. Pemanfaatan sabut kelapa yang tidak kalah menarik adalah sebagai cocopeat yaitu sabut kelapa yang diolah menjadi butiran-butiran gabus sabut kelapa. Cocopeat dapat menahan kandungan air dan unsur kimia pupuk serta dapat menetralkan keasaman tanah. Karena sifat tersebut, sehingga cocopeat dapat digunakan sebagai media yang baik untuk pertumbuhan tanaman hortikultura dan media tanaman rumah kaca.

Daging kelapa dapat diolah kembali menjadi desiccated coconut yang merupakan produk pangan dan biasa digunakan sebagai bahan baku cookies, bakery, dan produk camilan lainnya. Selain itu daging kelapa juga dapat diolah menjadi virgin coconut oil (minyak kelapa murni) yang memiliki kandungan berkhasiat dalam hal kesehatan, kekebalan tubuh, dan penyembuhan berbagai macam 
penyakit yang disebabkan oleh terdapatnya kandungan asam laurat yang tinggi di dalam minyak kelapa murni tersebut. Kopra dibuat dari bahan baku daging buah kelapa. Untuk memperoleh daging buah kelapa biasanya ditempuh dengan jalan memisahkan sabut yang merupakan pembungkus daging buah kelapa paling luar yang mempunyai ketebalan 5-10 cm. Di dalam sabut terdapat tempurung dengan tebal 3-5 mm. Di dalam tempurung terdapat daging buah yang diantarnya terdapat selaput tipis berwarna cokelat, disebut testa. Pada waktu daging buah dikeringkan dan dipisahkan dari tempurungnya maka testa akan melekat pada daging buah kelapa. Dengan menurunkan kadar air daging buah kelapa dari kurang lebih 50\% ke 5\% dapat diperoleh keinginan-keinginan antara lain untuk mengawetkan daging buah kelapa tersebut, mengurangi berat (menjadi 52\% dari bobot awal), dan mengkonsentrasikan minyak (kadar minyak kopra 65-68\%, daging buah kelapa 54\%) (Dirjenbun, 2006). Berbagai alternatif produk turunan kelapa yang dapt dihasilkan dari tanaman kelapa disajikan pada gambar 1 .

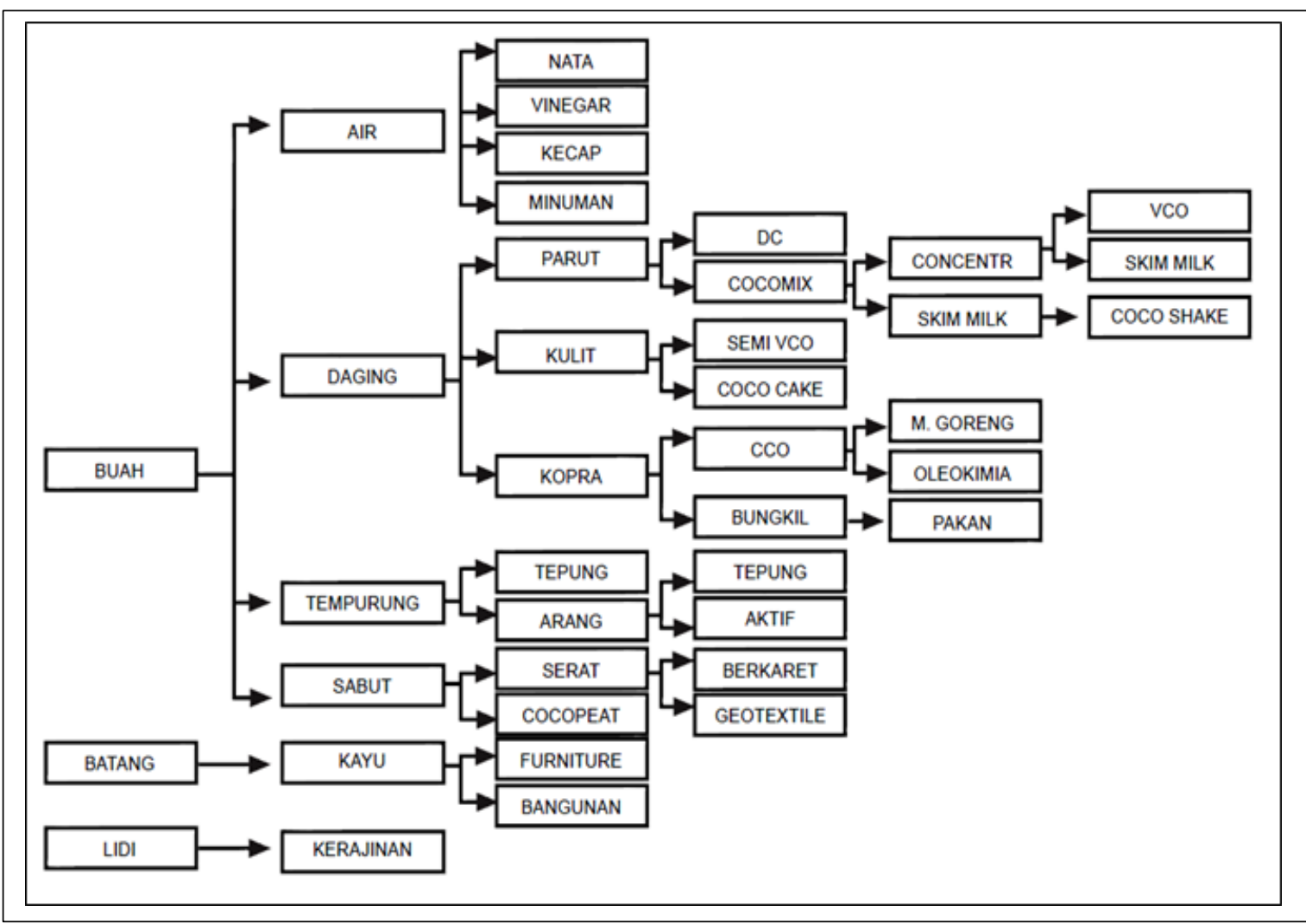

Gambar 1. Alternatif Produk Turunan Kelapa

\section{METODE}

Penelitian ini dirancang sebagai penelitian pengembangan (research and develepment) karena dimaksudkan untuk mengembangkan produk kelapa yang sudah ada saat ini sehingga diharapkan dapat meningkatkan daya saing produk kelapa dimasa mendatang. Lokasi penelitian akan dilakukan di wilayah
Provinsi Gorontalo terutama di daerah-daerah yang merupakan sentra penghasil produk kelapa yang tersebar di beberapa kecamatan di wilayah Kabupaten/Kota di Provinsi Gorontalo.

Objek penelitian adalah seluruh pihak yang terlibat dalam rantai usaha kelapa baik pemerintah, petani, pengumpul (besar maupun 
kecil), pengusaha kopra, pemilik pabrik, dan ekspotir.

Jenis data yang diperlukan dalam penelitian ini adalah data primer dan data sekunder. Sumber data primer diperoleh dari hasil observasi langsung di lapangan dan angket dan wawancara kepada para pihak yang terkait (masyarakat, pengusaha, serta pihak Pemerintah Daerah). Sumber data sekunder adalah data yang diperoleh dari instansi pemerintah maupun instansi resmi lainya yang ada kaitannya dengan masalah yang diteliti.

Teknik analisis data yang akan digunakan dalam penelitian ini adalah sebagai berikut :

\section{1) Analisis Deskriptif}

Analisis desktiptif ini digunakan sebagai analisis awal untuk menggambarkan kondisi pemanfaatn produk kelapa saat ini (existing). Indikator yang akan dianalisis secara deskriptif adalah indikator yang berkaitan dengan potensi dan tingkat pemanfaatan produk kelapa.

\section{2) Analisis AHP (Analytical Hierarchy Process)}

Metode AHP pada dasarnya adalah sebuah hirarki fungsional dengan input utamanya persepsi dan preferensi manusia. Masalah yang komplek dan tidak terstruktur diuraikan ke dalam kelompok atau kriterianya, kemudian kelompok ini variabel-variabel setiap kriteria, komponen kriteria, dan altematif keputusan ditentukan melalui pemberian nilai numerik secara subyektif tentang arti pentingnya secara relatif dibandingkan variabel yang lain pada levelnya. Tujuan penggunaan AHP adalah untuk merumuskan bobot kepentingan berbagai faktor yang nantinya akan digunakan sebagai dasar perumusan strategi.

\section{HASIL DAN PEMBAHASAN}

\section{Potensi Kelapa di Provinsi Gorontalo Perkembangan Luas Tanam}

Perkembangan luas areal tanam komoditas kelapa di wilayah Provinsi Gorontalo dapat dilihat dalam tabel 1.
Tabel 1. luas areal tanam komoditas kelapa di wilayah Provinsi Gorontalo

\begin{tabular}{|l|r|r|r|r|}
\hline \multirow{2}{*}{ Wilayah } & \multicolumn{4}{|c|}{ Luas Tanam (Ha) } \\
\cline { 2 - 5 } & $\mathbf{2 0 1 2}$ & $\mathbf{2 0 1 3}$ & $\mathbf{2 0 1 4}$ & \multicolumn{1}{c|}{$\mathbf{2 0 1 5}$} \\
\hline Boalemo & 8,430 & 8,678 & 8,278 & 8,575 \\
\hline Gorontalo & 21,008 & 21,348 & 21,745 & 23,735 \\
\hline Pohuwato & 17,495 & 17,625 & 20,990 & 20,451 \\
\hline Bone Bolango & 7,470 & 7,636 & 7,089 & 7,651 \\
\hline Gorontalo Utara & 11,263 & 11,513 & 10,794 & 12,212 \\
\hline Provinsi & $\mathbf{6 5 , 6 6 6}$ & $\mathbf{6 6 , 8 0 0}$ & $\mathbf{6 8 , 8 9 6}$ & $\mathbf{7 2 , 6 2 4}$ \\
\hline
\end{tabular}

Berdasarkan tabel 1 terlihat bahwa luas tanam komoditas kelapa di Provinsi Gorontalo secara keseluruhan mengalami peningkatan dari tahun ke tahun. Pada tahun 2012 luas areal tanam kelapa seluas 65,67 ribu hektar meningkat menjadi 66,8 ribu hektar pada tahun 2013 dan menjadi 68,89 ribu hektar. Pada tahun 2015, luas areal tanam kelapa kembali mengalami peningkatan signifikan menjadi 72,62 ribu hektar. Namun jika dilihat per kabupaten, peningkatan luas tanam kelapa tidak merata pada setiap daerah. Peningkatan luas areal tanam komoditas kelapa tertinggi terdapat di Kabupaten Pohuwato dan Kabupaten Gorontalo. Pada tahun 2012, luas areal tanam di Kabupaten Pohuwato sebesar 17,5 ribu hektar yang kemudian meningkat menjadi 20,45 ribu hektar pada tahun 2015 atau meningkat sebesar kurang lebih 3 ribu hektar. Sementara di Kabupaten Gorontalo, luas tanam kelapa mengalami peningkatan sebesar 3,7 ribu hektar dari 21,05 ribu hektar pada tahun 2012 menjadi 23,74 ribu hektar pada tahun 2015.

\section{Perkembangan Hasil Produksi Kelapa}

Adapun untuk perkembangan hasil produksi kelapa di setiap daerah dapat dilihat dalam tabel 2.

Dari data pada tabel 2 terlihat bahwa sepanjang tahun 2012-2014 produksi kelapa di wilayah Provinsi Gorontalo menunjukkan peningkatan dari 61,19 ribu ton pada tahun 2012 mengalami peningkatan menjadi 63,38 ribu ton pada tahun 2013 dan kembali meningkat pada tahun 2014 menjadi 66,79 ribu ton. 
Tabel 2. Data Perkembangan Hasil Produksi Kelapa

\begin{tabular}{|l|r|r|r|r|}
\hline \multirow{2}{*}{ Wilayah } & \multicolumn{4}{|c|}{ Produksi Kelapa (Ton) } \\
\cline { 2 - 5 } & $\mathbf{2 0 1 2}$ & $\mathbf{2 0 1 3}$ & $\mathbf{2 0 1 4}$ & $\mathbf{2 0 1 5}$ \\
\hline Boalemo & 7,232 & 7,416 & 7,761 & 4,737 \\
\hline Gorontalo & 21,989 & 22,672 & 23,658 & 21,043 \\
\hline Pohuwato & 17,177 & 17,864 & 19,750 & 18,269 \\
\hline Bone Bolango & 6,007 & 6,354 & 6,354 & 2,379 \\
\hline Gorontalo Utara & 8,787 & 9,080 & 9,270 & 8,367 \\
\hline Provinsi & $\mathbf{6 1 , 1 9 2}$ & $\mathbf{6 3 , 3 8 6}$ & $\mathbf{6 6 , 7 9 3}$ & $\mathbf{5 4 , 7 9 5}$ \\
\hline
\end{tabular}

Namun pada tahun 2015 produksi kelapa mengalami penurunan cukup signifikan menjadi 54,79 ribu ton. Penurunan jumlah produksi ini terjadi secara serentak di seluruh wilayah Provinsi Gorontalo. Penurunan jumlah produksi ini lebih banyak disebabkan oleh menurunnya tingkat produktivitas kelapa yang dihasilkan. Hal ini dikarenakan banyaknya pohon kelapa yang sudah berusia tua dan minimnya upaya meremajakan pohon kelapa yang sudah ada.

\section{Analisis Produk Turunan Kelapa Yang Potensial untuk Dikembangkan di Wilayah Provinsi Gorontalo}

Setelah kajian terhadap beberapa potensi turunan kelapa dilakukan maka selanjutnya akan dilakukan analisis lebih lanjut untuk melhat produk turunan kelapa yang paling potensial untuk dikembangkan di wilayah Provinsi Gorontalo. Adapun indikator yang akan digunakan dalam penentuan produk turunan kelapa yang potensial dikembangkan di wilayah Provinsi Gorontalo adalah aspek bahan baku, aspek pasar, aspek produksi/teknologi, aspek modal, aspek dukungan pemerintah.

Analisis yang akan digunakan untuk penelitian ini adalah analisis AHP (Analytical Hierarchy Process) dan analisis MPE (Matriks Perbandingan Eksponensial). Analisis AHP digunakan untuk menentukan bobot dari setiap kriteria yang akan digunakan dalam penentuan produk kelapa potensial. Adapun hierarki untuk penentuan produk unggulan kelapa disajikan pada gambar 2 .

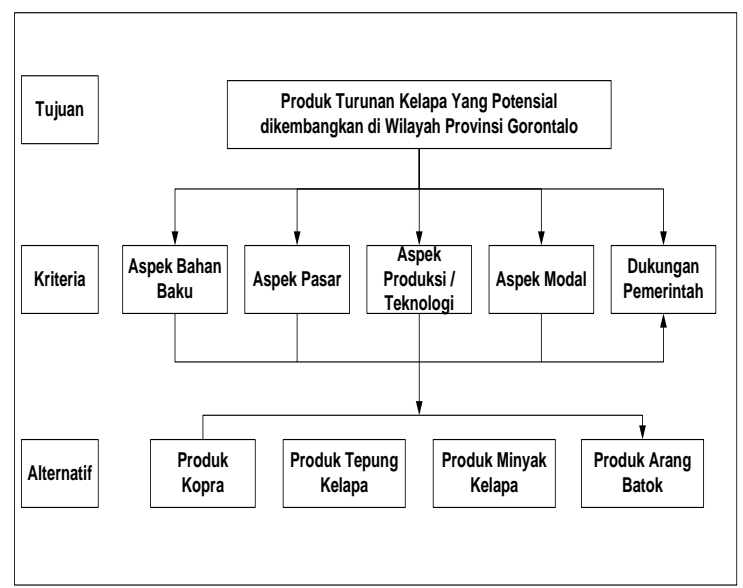

Gambar 2. hierarki untuk penentuan produk unggulan kelapa

\section{1) Perbandingan Bobot Kriteria dalam Penentuan Produk Turunan Kelapa Potensial}

Hasil analisis AHP untuk bobot masing-masing kriteria yang akan digunakan dalam penentuan produk turunan kelapa yang potensial dikembangkan di wilayah Provinsi Gorontalo disajikan pada gamabr 3 . Berdasarkan hasil analisis pada gambar 3 terlihat bahwa dari lima aspek yang akan digunakan dalam penentuan produk turunan kelapa yang potensial, aspek yang memiliki bobot tertinggi adalah aspek modal dengan bobot sebesar 0,362. Selanjutnya adalah aspek pasar $(0,323)$, aspek bahan baku $(0,154)$, aspek dukungan pemerintah $(0,101)$ dan aspek produksi/teknologi $(0,060)$. 


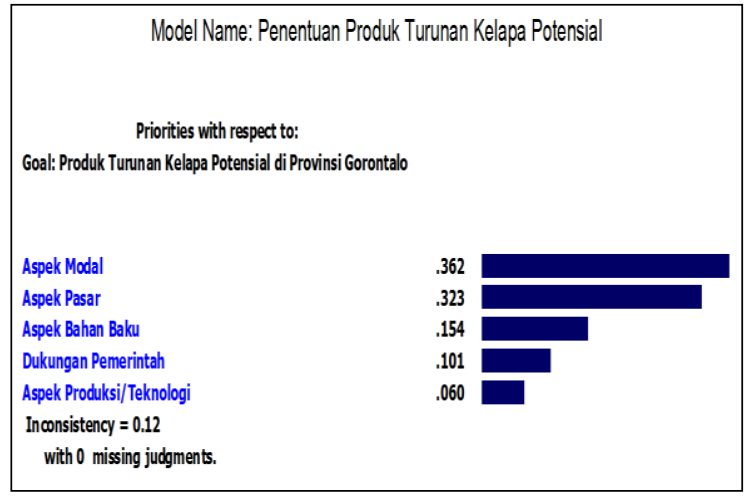

Gambar 3. Hasil analisis AHP

\section{2) Perbandingan Produk Turunan Kelapa dilihat Dari Aspek Bahan Baku}

Hasil analisis perbandingan setiap produk turunan kelapa yang potensial dikembangkan di wilayah Provinsi Gorontalo dilihat dari ketersediaan bahan baku disajikan pada gambar 4 .

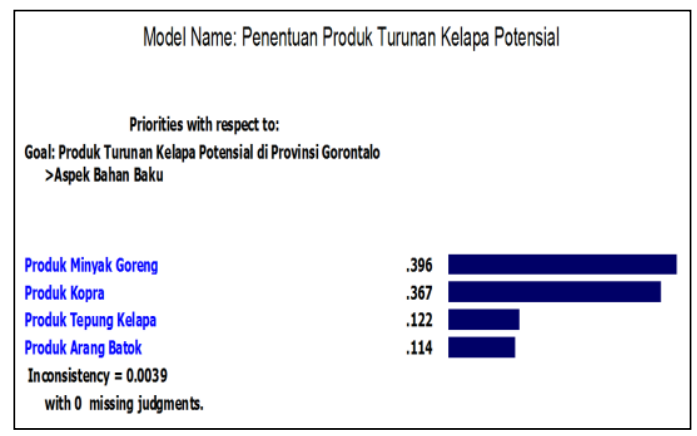

Gambar 4. Hasil analisis Perbandingan

Berdasarkan hasil analisis diatas terlihat bahwa dari kondisi ketersediaan bahan baku, produk turunan kelapa yang memiliki bobot tertinggi adalah produk minyak goreng dengan bobot sebesar 0,396 yang diikuti oleh produk kopra dengan bobot sebesar 0,367. Sedangkan untuk produk tepung kelapa memiliki bobot sebesar 0,122 dan untuk produk arang batok memiliki bobot sebesar 0,114.

\section{3) Perbandingan Produk Turunan Kelapa dilihat Dari Aspek Pasar}

Hasil analisis perbandingan setiap produk turunan kelapa yang potensial dikembangkan di wilayah Provinsi Gorontalo dilihat dari kondisi pasar disajikan pada gambar 5.

\begin{tabular}{|l|}
\hline \multicolumn{2}{|c|}{ Model Name: Penentuan Produk Turunan Kelapa Potensial } \\
Priorities with respect to: \\
Goal: Produk Tunnan Kelapa Potensial di Provinsi Gorontalo \\
$>$ Aspek Pasar \\
Produk Minvak Goreng \\
Produk Tepung Kelapa \\
Produk Kopra \\
Produk Arang Batok \\
Inconsistency $=0.09$ \\
with0 missing judgments.
\end{tabular}

Gambar 5. Hasil analisis Perbandingan

Berdasarkan hasil analisis di atas terlihat bahwa dilihat dari kondisi pasar yang dihadapi, produk turunan kelapa yang memiliki bobot tertinggi adalah produk minyak goreng dengan bobot sebesar 0,371 yang diikuti oleh produk tepung kelapa dengan bobot sebesar 0,345. Sedangkan untuk produk kopra memiliki bobot sebesar 0,175 dan untuk produk arang batok memiliki bobot sebesar 0,110.

\section{4) Perbandingan Produk Turunan Kelapa dilihat Dari Aspek Produksi/ Teknologi}

Hasil analisis perbandingan setiap produk turunan kelapa yang potensial dikembangkan di wilayah Provinsi Gorontalo dilihat dari proses produksi dan penggunaan teknologi dalam produksi disajikan pada gambar 6 .

Berdasarkan hasil analisis pada gambar 6 terlihat bahwa dilihat dari proses produksi dan kemudahan teknologi produksi, produk turunan kelapa yang memiliki bobot tertinggi adalah produk minyak goreng dengan bobot sebesar 0,405 yang diikuti oleh produk kopra dengan bobot sebesar 0,300. Sedangkan 
untuk produk arang batok memiliki bobot sebesar 0,216 dan untuk produk tepung kelapa memiliki bobot sebesar 0,079 .

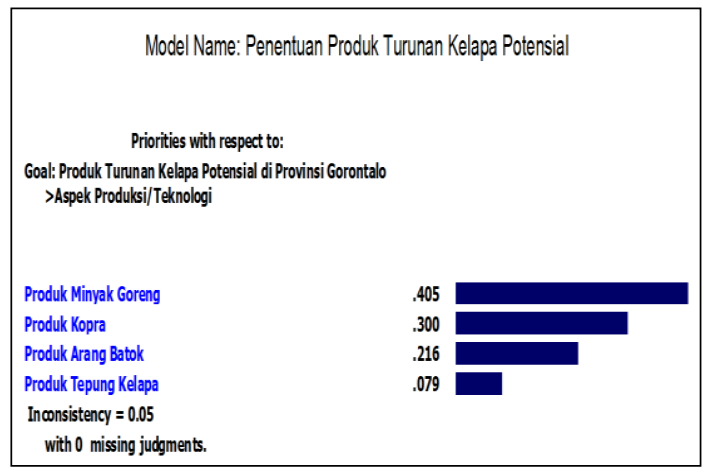

Gambar 6. Hasil Analisis Perbandingan Setiap Produk Turunan Kelapa.

\section{5) Perbandingan Produk Turunan Kelapa dilihat Dari Aspek Modal}

Hasil analisis perbandingan setiap produk turunan kelapa yang potensial dikembangkan di wilayah Provinsi Gorontalo dilihat dari kondisi dan dukungan modal yang dimiliki adalah sebagai berikut :

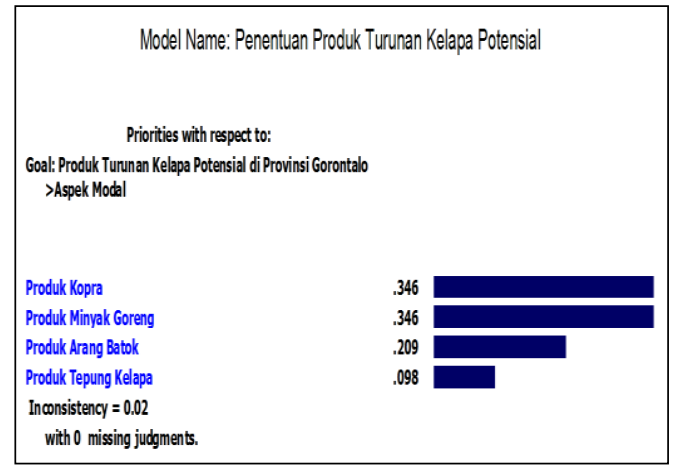

Gambar 7. Kondisi Ketersediaan Dan Dukungan Modal

Berdasarkan hasil analisis di atas terlihat bahwa dilihat dari kondisi ketersediaan dan dukungan modal yang dimiliki, produk turunan kelapa yang memiliki bobot tertinggi adalah produk kopra dan produk minyak goreng dengan bobot sebesar 0,346. Sedangkan untuk produk arang batok memiliki bobot sebesar 0,209 dan untuk produk tepung kelapaa memiliki bobot sebesar 0,098.

\section{6) Perbandingan Produk Turunan Kelapa dilihat Dari Aspek Dukungan Pemerintah}

Hasil analisis perbandingan setiap produk turunan kelapa yang potensial dikembangkan di wilayah Provinsi Gorontalo dilihat dari dukungan pemerintah terhadap pengembangan usaha adalah sebagai berikut :

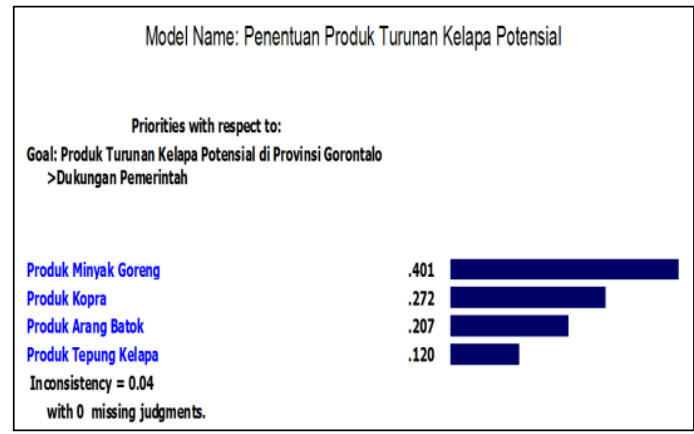

Gambar 8. Dukungan Pemerintah Terhadap Perkembangan Usaha.

Berdasarkan hasil analisis diatas terlihat bahwa dilihat dari dukungan pemerintah terhadap perkembangan usaha, produk turunan kelapa yang memiliki bobot tertinggi adalah produk minyak goreng dengan bobot sebesar 0,401 yang diikuti oleh produk kopra dengan bobot sebesar 0,272. Sedangkan untuk produk arang batok memiliki bobot sebesar 0,207 dan untuk produk tepung kelapa memiliki bobot sebesar 0,120 .

\section{7) Hasil Penentuan Produk Turunan Kelapa yang Potensial Dikembangkan di Provinsi Gorontalo}

Hasil sintesis dari analisis AHP untuk penentuan produk turunan kelapa yang potensial dikembangkan di wilayah Provinsi Gorontalo dengan menggunakan 
kriteria yang telah dipaparkan sebelumnya dapat dilihat dalam gambar berikut ini :

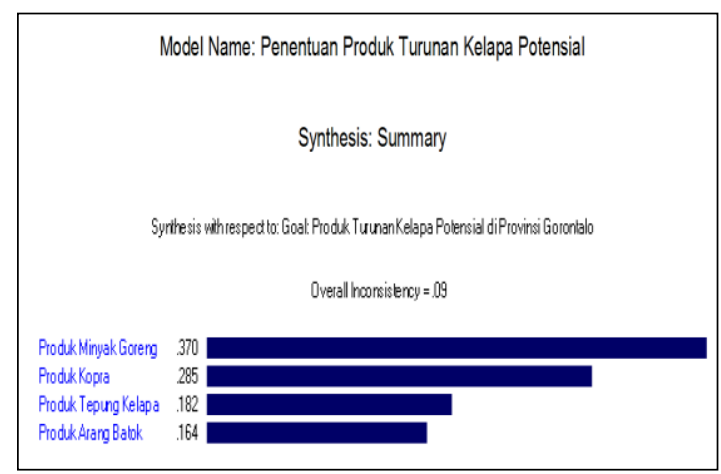

Gambar 9. Empat Produk Turunan Kelapa Yang Dianalisis

Berdasarakan hasil sintesis dari analisis AHP di atas terlihat bahwa dari empat produk turunan kelapa yang dianalisis, produk yang memiliki bobot tertinggi adalah minyak goreng dengan bobot sebesar 0,370. Produk selanjutnya adalah kopra $(0,285)$, produk tepung kelapa $(0,182)$ dan produk arang batok $(0,164)$

\section{PENUTUP}

\section{Kesimpulan}

Berdasarkan analisis yang dilakukan dapat diambil beberapa kesimpulan sebagai berikut :

1. Potensi pengembangan produk olahan kelapa di wilayah Provinsi Gorontalo masih terbuka luas. Hal ini karena ketersediaan bahan baku kelapa yang cukup melimpah.

2. Beberapa produk olahan kelapa yang potensial dikembangkan oleh masyarakat antara lain minyak kelapa, arang batok, dan briket arang. Sementara untuk skala ekonomi yang lebih luas, produk olahan yang dapat dikembangkan adalah tepung kelapa dan tepung tempurung kelapa.

3. Dari beberapa alternatif produk turunan kelapa yang telah dikembangkan di masyarakat, produk minyak goreng merupakan produk turunan kelapa yang paling potensial untuk dikembangkan lebih lanjut.

4. Produk minyak goreng memiliki keunggulan dalam hal permintaan pasar yang sangat tinggi, proses produksi yang tidak terlalu kompleks dan teknologi produksi yang cukup sederhana. Selain itu produk minyak goreng juga telah banyak dikembangkan oleh masyarakat secara tradisional

\section{Saran}

Berdasarkan kesimpulan maka peneliti memberikan beberapa saran sebagai berikut:

1. Perlu adanya analisis yang lebih lanjut terutama dari aspek ekonomi dan finansial untuk produk olahan kelapa yang potensial untuk dikembangkan.

2. Perlu adanya perhatian khusus dari dinas terkait untuk upaya peremajaan pohon kelapa yang ada di wilayah Provinsi Gorontalo. Tujuannya untuk menjamin kelangsungan pasokan bahan baku bagi industri-industri berbasis kelapa.

\section{UCAPAN TERIMA KASIH}

Terima kasih kepada Kementerian Riset, Teknologi Dan Pendidikan Tinggi dan Universitas Negeri Gorontalo yang telah membantu dalam hal pendanaan penelitian ini.

\section{DAFTAR PUSTAKA}

Abner Lay, Patrik M. (2010). Strategi dan Implementasi Pengembangan Produk Kelapa Masa Depan. Manado : Balai Penelitian Tanaman Kelapa dan Palma Lain.

Andri, K.B. (2009). Pengantar Pemahaman SCM dan VCA Komoditas Pertanian. Bahan Lokakarya Value Chain Analysis (Analisis Rantai Nilai) Tanggal 5-7 Juni 2009 di Mataram, NTB. Badan Litbang Pertanian. 
Badan Koordinasi Penanaman Modal. (2009).

Profil Potensi Investasi Provinsi Gorontalo. Jakarta

Bank Indonesia. (2004). Pola Pembiayaan Usaha Kecil Industri Minyak Kelapa. Jakarta : Direktorat Kredit, BPR dan UMKM Bank Indonesia

David Allorerung, dkk. (2008). Peluang Kelapa untuk Pengembangan Produk Kesehatan. Jurnal Pengembangan Inovasi Pertanian. 1(4), 2008 : 298-315

Departemen Perindustrian. (2009). Roadmap Industri Pengolahan Kelapa. Jakarta: Direktorat Jenderal Industri Agro dan Kimia Departemen Perindustrian.

Miftahorrahman. (2008). Evaluasi keragaman plasma nutfah kelapa Dalam di Gorontalo. Buletin Palma. 34: 42- 41.

Palungkun, R. (1998). Aneka Produk Olahan Kelapa. Jakarta :Penebar Swadaya.

Pusat Penelitian dan Pengembangan Perkebunan. (2005). Varietas Unggul Tanaman Perkebunan. Bogor : Pusat Penelitian dan Pengembangan Perkebunan Badan Penelitian dan Pengembangan Pertanian. 